\title{
Editorial
}

\section{AfTEr ÅKERBERG FRANSSON AND MELLONI}

Once again, the relationship between national and European constitutional law has come to the forefront of case-law and academia with the recent Akerberg Fransson and Melloni judgments of the European Court of Justice (ECJ). These judgments more specifically concern the relationship between national fundamental rights and those in the EU Charter of fundamental rights. The bottom line of Fransson is that 'the fundamental rights guaranteed by the Charter must be complied with where national legislation falls within the scope of European Union law'; ${ }^{1}$ that of Melloni is that

where an EU legal act calls for national implementing measures, national authorities and courts remain free to apply national standards of protection of fundamental rights, provided that the level of protection provided for by the Charter, as interpreted by the Court, and the primacy, unity and effectiveness of EU law are not thereby compromised. ${ }^{2}$

In combination, these rulings have the potential to marginalise national fundamental rights protection and perhaps even national constitutions, as Filippo Fontanelli remarks in his case note on Fransson in this issue.

The fundamental question Fransson and Melloni raise is whether a situation in which fundamental rights protection on the basis of the Charter becomes the rule and protection based on national constitutional law the exception is compatible with - in Fontanelli's words - 'the EU's mission and authority.' On this matter, opinions clearly differ. András Jakab, for instance, pleads for the applicability of the Charter even in purely domestic matters, lest the EU, 'which is not just a community based on common interests but is also a community of values', lose its credibility. ${ }^{3}(\mathrm{O}) \mathrm{n}$ a proper interpretation of the basic constitutional structure

\footnotetext{
${ }^{1}$ ECJ 23 Feb. 2013, C-617/10, Åkerberg Fransson, para. 21.

${ }^{2}$ ECJ 26 Feb. 2013, C-399/11, Melloni, para. 60.

${ }^{3}$ András Jakab, 'Supremacy of the EU Charter in National Courts in Purely Domestic Cases', <www.verfassungsblog.de/en/hungary-taking-action-andras-jakab/>, visited on 20 June
} 2013.

European Constitutional Law Review, 9: 169-175, 2013

(C) 2013 T.M.C.ASSER PRESS and Contributors

doi:10.1017/S1574019612001095 
of the compound comprising the Union and the Member States, which has been described as the "European Verfassungsverbund", Advocate-General Cruz Villalón, in his opinion in Fransson, comes to a radically different proposal: the general rule is and should remain that the member states 'themselves, in the context of their own constitutional order and the international obligations which they have entered into, (...) review acts of their public authorities.' The exception to this rule, i.e., the EU taking over the responsibility for fundamental rights protection, should only apply when the member states have transferred this responsibility to the Union and the 'lawfulness of public authority in the Union may be at stake.' Whether there has been such a transfer must be decided on an individual, case-to-case basis; ${ }^{4}$ in his view, in the specific case of Fransson it had not taken place.

There is a second dimension of this discussion on the scope of applicability of the Charter. The different positions may be related to different views on the universality versus the historicity of (the identification, interpretation and qualification of) fundamental rights. If one emphasises the universal, deductive and natural law-like character of human rights, as values and rights common to all human beings, it becomes more or less 'natural' to adhere to what Marta Cartabia, in a seminal article in this review, has called the 'widespread legal thought that (...) the whole continent can be unified around universally shared values and that unification flows from the judges' pens'. ${ }^{5}$ Advocate-General Bot, in his opinion in Melloni, positions himself at the other end of the spectrum and takes the historicity of human rights as point of departure. He writes that

(t)he fundamental rights to be protected and the level of protection to be afforded to them reflect the choices of a society as regards the proper balance to be achieved between the interests of individuals and those of the community to which they belong. That determination is closely linked to assessments which are specific to the legal order concerned, relating particularly to the social, cultural and historical context of that order, and cannot therefore be transposed automatically to other contexts. ${ }^{6}$

Bot used this reasoning to justify his conclusion that the member states in the 'EU society' are not allowed to apply a constitutional rule which guarantees a higher level of protection than the Union itself guarantees if this runs counter to the effectiveness of a secondary Union act. However, his reasoning is a double-edged sword. If indeed fundamental rights protection is the result and reflection of social, cultural and historical processes in a given society, this is not only true for the 'EU society', but also for the national societies. This brings to the fore what is at stake

\footnotetext{
${ }^{4}$ Opinion of AG Cruz Villalón of 12 June 2012 in Case C-617/10, Åkerberg Fransson, paras. 35-41.

${ }^{5}$ Marta Cartabia, 'Europe and Rights: Taking Dialogue Seriously', EuConst (2009) p. 5 (19-20).

${ }^{6}$ Opinion of AG Bot of 2 Oct. 2012 in Case C-399/11, Melloni, para. 109.
} 
here: the inversion of the rule that primarily the member states themselves are responsible for fundamental rights protection would engender the danger that fundamental rights protection becomes dissociated from the still primarily national societies in which it has to function. Moreover, to quote Cartabia once again, 'it engenders the risk of sacrificing the national historical and cultural traditions that characterise the pluralistic nature of Europe' (p. 20).

There is yet another possible victim: national balances of powers. The national constitutional courts' authority and legitimacy is to a considerable extent built on the fundamental rights protection they offer. Dislocating fundamental rights protection from the national arena may undermine and erode the functioning of these courts in the national constitutional spheres and therefore affect the national trias politica. This is all the more because it is ordinary courts that refer questions to the ECJ, which in turn determines the applicable fundamental rights standard, and finally it is ordinary courts that apply European law, side-stepping national constitutional issues as they might have played out in constitutional courts.

To this may be added that the erosion of the rule that, generally, the member states themselves are responsible for determining the substance of fundamental rights protection it also has implications for the relationship between law and politics. Interpretations of national constitutional courts can be overruled by the constitutional legislature - and at least in a member state like France this has happened. In principle, this is, mutatis mutandis, also possible with the interpretations of the Court of Justice, but as we all know, compared to the national constitutions the Union's constitution is extremely rigid. It requires a treaty amendment and therefore unanimity to set aside a ruling of the Court of Justice. The threshold is almost insurmountably high.

Although the Court of Justice in Fransson and Melloni decided that in these cases the yardstick should be the Charter, and not national fundamental rights, it is far from settled yet that fundamental rights protection via the Charter by now has become the general rule, and protection on the basis of other sources the exception. For instance, although the Court clarified in Fransson that the scope of application of the Charter is identical to the scope of application of EU law, the outer limits of the latter remain shrouded in mist. As Fontanelli writes in his case note, a crucial question is whether acts of the member states which are only more or less accidentally connected to Union law also fall within its scope. The German constitutional court, the Bundesverfassungsgericht, already made clear that it would not accept such an extensive interpretation in a recent decision ${ }^{7}$ on which Fontanelli also reports in his case note; the background of this decision will be the subject of a separate contribution in the next issue of this review.

${ }^{7}$ BVerG, 1 BvR 1215/07 of 24 April 2013, paras. 88-91. 
Nevertheless, even if it is not certain where Union law begins and ends at this moment, it is certain that its scope will expand with the use that the Union legislature makes of its 'new' competences, especially in the field of home affairs and justice, domains in which fundamental rights are perhaps even more fundamental than in other domains. Here Melloni comes into play. The question that judgment raises is how much room the Court of Justice is willing to leave for national provisions providing for a higher protection. Indeed, willing to leave, because according to the Court such exceptions are only allowed on the conditions that 'the Charter, as interpreted by the Court, and the primacy, unity and effectiveness of EU law are not thereby compromised.' It should be noted that every exception to Union law may be considered to compromise the unity (note: not the uniformity!) of Union law. In theory, therefore, all reins are in the hands of the Union court.

In practice, however, here too will the Court have to deal with national constitutional courts. Whoever thought that the fundamental rights skirmishes between the Bundesverfassungsgericht and the Court of Justice are history since the famous Solange II and Bananas decisions, ${ }^{8}$ is mistaken. At least the potential for further conflict has reappeared under another name, that of constitutional identity - this concept is also reflected in the famous Article 4(2) of the Union Treaty since Lisbon, at least according to the Bundesverfassungsgericht itself. ${ }^{9}$ Other constitutional courts employ the concept too, albeit not always under that name. Whatever the differences between the terms used and the scopes initially envisaged for them, there is one thing that all these national controlimiti have in common: their interpretation is in the hands of the national courts. It would not surprise us if the extension of the applicability of the Charter were to fuel an extensive interpretation of these national 'counterlimits'. The post-Landtová judgment of the Czech Constitutional Court, which declared a judgment of the Court of Justice ultra vires for its 'failure to respect European history', ${ }^{10}$ might be an omen in this respect.

There is another area in which national fundamental rights will remain of paramount importance: the negotiation phase of secondary Union acts. For that, let's first go to the facts of Melloni.

On 26 February 2009, Framework Decision 2009/299/JHA inserted Article 4(a) into the 2002 European Arrest Warrant Framework Decision. This Article, pivotal in Melloni, severely restricts the possibilities of a state to refuse the execution of a European Arrest Warrant for the purposes of executing a custodial sentence

\footnotetext{
${ }^{8}$ BVerGE 73, 339 (22 Oct. 1986, Solange II); BVerfGE 102, 147 (7 June 2000; Bananas).

${ }^{9}$ BVerfG 30 June 2009, 2 BvE 2/08 (Lisbon), para. 240

${ }^{10}$ Jan Komárek, 'Czech Constitutional Court Playing with Matches: The Czech Constitutional Court Declares a Judgment of the Court of Justice of the EU Ultra Vires' Judgment of 31 Jan. 2012, Pl. ÚS 5/12, Slovak Pensions XVIT, EuConst (2012) p. 323 at p. 330.
} 
or a detention order if the person in question was tried in absentia. Just like all other Framework Decisions, the 2009 Framework Decision had to be accepted unanimously by the members of the Council. The Spanish representative therefore agreed to the Decision, although he (or she) should have been aware of a 2006 judgment of the Spanish Constitutional Court. In this decision, the Spanish Court extended its case-law that the right to participate personally in a trial is part of the 'absolute content' of the right to a fair trial as enshrined in Article 24 of the Spanish Constitution to the execution of European Arrest Warrants; therefore the execution of an arrest warrant should be refused if the person concerned had been tried in absention and had no right to a retrial in the requesting state. ${ }^{11}$ So the Spanish representative in 2009 consented to a Framework Decision which he presumably knew, or at least should have known, to be in violation of the Spanish Constitution as previously interpreted by the Spanish Constitutional Court. This state of affairs begs several questions.

The first is whether a representative in the Council who, in the words of Article 16(2) EU, 'may commit the government of the Member State in question', is allowed to commit his state to a draft Union act which is contrary to its constitution. This is a question of national constitutional law. Generally, one must assume that the answer is negative: all ministers of the member states will have sworn to uphold their national constitutions upon their accession to office. If the answer were positive, it would give national governments the possibility to circumvent their national constitutions without going through the prescribed procedures for constitutional amendment. Moreover, from the EU point of view, there is no presumption that infringing on their national constitutional law can be demanded from member state representatives, notwithstanding the ECJ's classic position that once binding under EU law, at least the directly effective decisions will prevail over contrary national law.

Nevertheless, the answer might be less black-and-white when a member state has consecrated EU membership in constitutional law. For instance, France has done so in Article 88-1 of its Constitution. On the basis of this article, the Conseil constitutional has ruled that acts of parliament implementing secondary Union law are immune from constitutional review unless they violate the constitutional identity of France and the constitutional legislature has not consented thereto. Does this give license to the French representative in the Council to agree to draft decisions which are contrary to the Constitution but do not violate French constitutional identity? We do not think so. Immunity from judicial review does not in itself entail the competence for the executive or members of the legislature to

\footnotetext{
${ }^{11}$ Aida Torres Pérez, 'Spanish Constitutional Court, Constitutional Dialogue on the European Arrest Warrant: The Spanish Constitutional Court Knocking on Luxembourg's Door; Spanish Constitutional Court, Order of 9 June 2011, ATC 86/2011', EuConst (2012) p. 105 at p. 107-108.
} 
act contrary to the constitution. Arguably, this is also the case for member states which more substantively exempt the operation of EU law in the domestic context from compliance with the constitution, like the Irish Bunreacht. Such constitutional provisions may be read as referring to the status of EU law once established in relation to national law, but not as license to infringe the constitution in the course of EU legislative (and executive) decision-making. ${ }^{12}$

However, if indeed a representative is bound by his or her national constitution when negotiating secondary Union acts, that does not necessarily imply that he or she is bound by a constitutional court's interpretation of that constitution in a given case. That depends on the status of that interpretation according to national constitutional law. Moreover, it is not always clear whether a draft act is contrary to a member state's constitution. In that case, the position would arguably be that it is for the representatives themselves, rather than the judiciary (whether or not triggered by private citizens seeking judicial protection), to determine whether certain decision-making in which they cooperate is in conflict with the national constitution. This is related to the fact that in the present state of European integration, member states are not discrete and homogenous entities.

All member states have some form of separation of powers. Each of these powers has a role to play in the compound European constitutional order: not only the executives, but also the national courts (the preliminary reference procedure gives them pride of place, but in their role of prime arbiters of cases involving EU law their role goes well beyond that) and the national parliaments (cf. Article 12 TEU). Each of these powers may have a view as to what their own national constitution entails for what they can and must and may not do when engaging in EU activities. We mentioned the Spanish government representative who chose to agree to an amendment of the European Arrest Warrant Framework that was clearly in conflict with the meaning the Spanish Constitutional Court gave to a Spanish constitutional provision. We have also seen in the Landtová case at the $\mathrm{ECJ}^{13}$ that the Czech government's position in court was at odds with that of its Constitutional Court, which in turn was at odds with the interpretation that the highest Czech administrative court gave to Czech constitutional provisions on the same matter. In fact, these divergences between authorities of one and the same member state reflect that there is no really exclusive and total monopoly of interpretation of the national constitution, not even in the fairly large number of member states with a constitutional court that putatively has such a monopoly.

\footnotetext{
${ }^{12}$ Is this also the case for, let's say, the French members of the European Parliament? Are they also bound to national constitutional law, elected as they are in their national constituency on the basis of rules which in essence can be said to be national rules, being representative for their national constituency? This may be a question which is harder to answer than that regarding the Council members.

${ }^{13}$ ECJ 22 June 2011, Case C-399/09.
} 
A further set of questions is what the $\mathrm{EU}$ institutions and their members are to do when a representative of a member state claims a draft EU measure to be in conflict with its constitution. Comity and political expediency may induce other representatives to accommodate such concerns. As to a legal obligation, one may refer to the duty under Article 4(3) TEU of full mutual respect in the sincere cooperation between Union and member states. Moreover, at least for those constitutional rules and principles which are expressive of national identity, the Union Treaty suggests the Union must accommodate constitutional problems in order to comply with its duty to respect the national identity inherent in the political and constitutional structure of the member state concerned (Article 4(2)). These provisions of EU law confirm the compound nature of the European constitutional order with the EU and member states, constitutions and the ECHR as its components.

This not only gives much food for thought, but also points to a large field of comparative constitutional law yet to be ploughed.

JHR/LB 